\title{
CREDIT RISK MODELS FOR FIVE MAJOR SECTORS IN INDONESIA
}

\author{
Ndari Surjaningsih, Ina Nurmalia Kurniati ${ }^{1}$, Reni Indriani ${ }^{2}$
}

\begin{abstract}
This paper analyze Nonperforming Loan ratio to total credit (NPL), as a proxy for credit risk, for five major economic sectors by utilizing panel data of 117 commercial banks in Indonesia over period 2000Q1 to 2016Q3. Our empirical analysis shows that real economic growth is the main driver that is negatively correlated with credit risks in all sectors. The inverse relation is also found in commodity and housing price. Commodity price inflation affects NPL in manufacturing industry and trade sectors, meanwhile housing price inflation influences NPL in manufacturing industry, trade, and construction sectors. In addition, decreased in policy rate will decline credit risk in commodity, trade, and other sectors, meanwhile nominal exchange rate only affects credit risks in other sector. Our assessment shows that credit risks in commodity and other sectors are more sensitive to real economic growth than those on manufacturing industry and trade sectors. Real economic growth elasticities to credit risk for commodity and other sectors are almost twice higher than for manufacturing industry and trade sectors. Thus, during economic contraction phase, NPL in commodity and other sectors will increase higher than NPL in manufacturing industry and trade sectors.
\end{abstract}

Keywords: Banking, Panel Data Models.

JEL classification codes: G21, C33

1 Senior researcher and researcher in Macroprudential Policy Department BI, email: ndari@bi.go.id and inanurmalia@bi.go.id

2 Consultant in Macroprudential Policy Department. 


\section{INTRODUCTION}

The global financial crises in 2008 show us the importance of financial stability assessment to withstand shocks. As an authority that has to safeguard financial system stability, central bank need to have models to assess risks in the banking industry, especially credit risk. Credit risk, as the most significant risk in Indonesia banking industry, usually assess during banking top down stress test implementation. It is important to be able to evaluate the potential impact of macroeconomic variable shocks in to banking variables.

There are at least three approaches to assess credit risk in the banking industry. The first approach is to model Nonperforming Loan ratio (NPL) using macroeconomic variables as determinants. On the second approach, credit risks are estimated using probability of default, i.e evaluate transition matrix of performing loan into nonperforming loan for each bank. The third approach is to model bank's provision without computing bank's NPL.

From those approaches, the nonperforming loan model is the most commonly used to determine the impact of macroeconomic conditions on banking risk. Compared to the other two alternatives, the first approach is more flexible in data it can be modeled at the aggregate level (total credit) as well as at a more granular level - by types of credit allocation or economic sector.

Based on that background, this study aims to analyze the determinant of NPL ratio in the Indonesian economy which is grouped into five main sectors, namely commodity sector, trade sector, manufacturing industry sector, construction sector, and others. The analysis was conducted using dynamic panel data approach from 117 commercial banks in Indonesia, covering both conventional and islamic banks from 2000Q1 to 2016Q3.

This study differs from previous studies in several aspects. In addition to using data of all commercial banks in Indonesia, this study aims to examine the impact of macroeconomic variable shocks on credit for differentiated economic sectors. The aggregate credit risk model (total credit) has some limitations as it could lead to an underestimation of credit losses for some specific banks. The disaggregation of credit provides a more detailed picture of credit risks in each sector.

The analysis showed that the credit risks, in all of the five sectors, are influenced by the real GDP growth as the primary macroeconomic variable. An increase in economic growth reduces loan risks as reflected in an increase in the NPL ratio, except in the construction sector. A fall in policy interest rates affects the NPL risks in commodity, trade and services sectors, as well as in other sectors. The nominal exchange rate only changes the ratio of the NPL to other sectors. The inflation, in the commodity prices, negatively affected the NPL ratio of both the trading and manufacturing sectors, while housing price inflation adversely affected the NPLs of three sectors, namely trade and services, manufacturing, and construction.

This study is divided into five sections. Chapter I provides a general introduction, while Chapter II describes stylized facts and literature review related to the determinants of bank loan risks. A description of the methodology and the data used are provided in Chapter III. Chapter IV discusses the results of estimation and analysis, while Chapter V will explain the conclusions and suggestions for further research. 


\section{THEORY}

The credit risk is seen as one of the most essential and enormous risks in the banking industry. Poor credit quality affects credit supply from bank (supply) and in turn, will have an impact on investment. Banking, as the dominant sector in the Indonesian financial sector, plays a vital role in the stability of the financial system.

\subsection{Overview of Banks Credit Disbursement}

The credit growth was still in the sluggish trend until the second semester of 2016. Loan disbursement showed a 7.86\% growth (yoy) lower than the first semester of 2016, which reached $8.89 \%$ (yoy). The combination between low demands of new loan with increasing level of prudential banking principle in disbursing credit contributed to the slower credit growth. The banking industry focused on the consolidation their nonperforming loans and took a more prudent approach in disbursing new loans (Bank Indonesia, 2017).

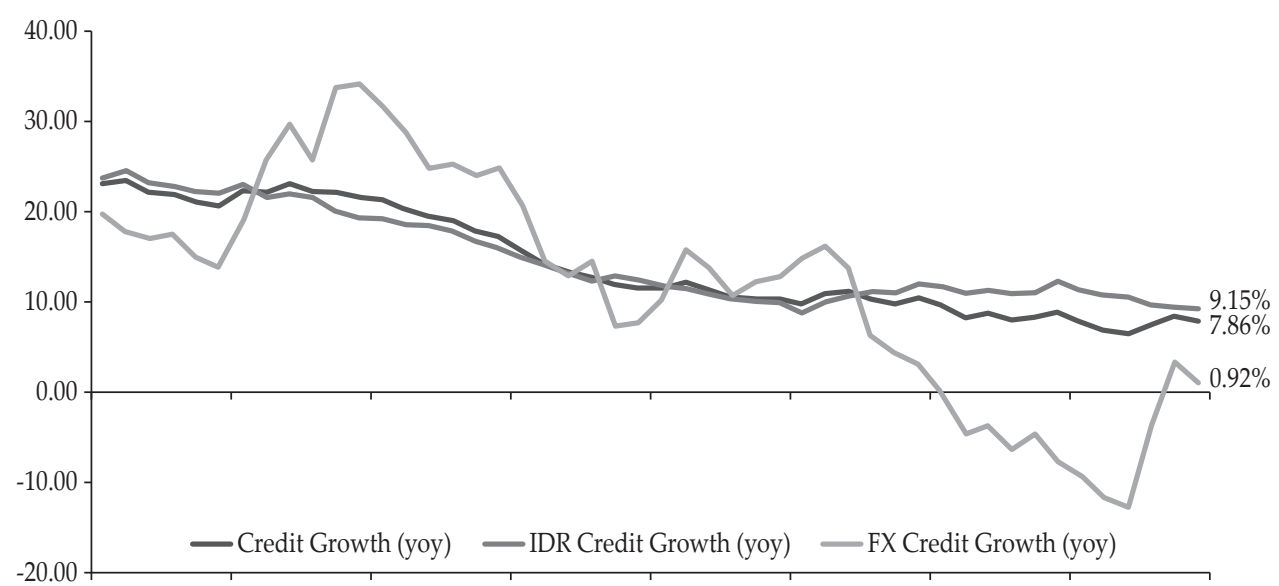

2013 - Sem I 2013 - Sem II 2014 - Sem I 2014 - Sem II 2015 - Sem I 2015 - Sem II 2016 - Sem I 2016 - Sem II

Graph 1. Bank Credit Growth

In this research, credit disaggregation was divided into five major economic sectors in Indonesia using data on credit between 2000Q1 through 2016Q3. Nominally credit distribution in the Indonesian banking system was dominated by other sector and the lowest credit distribution was noticed the construction sector (Graph 2). In the 2016Q3, the share of credit in other sectors to the total credits reached $42 \%$ ( $R p 1.7$ Trillion), while the percentage of the construction credit represented only 5\% (Rp 0.21 Trillion). 


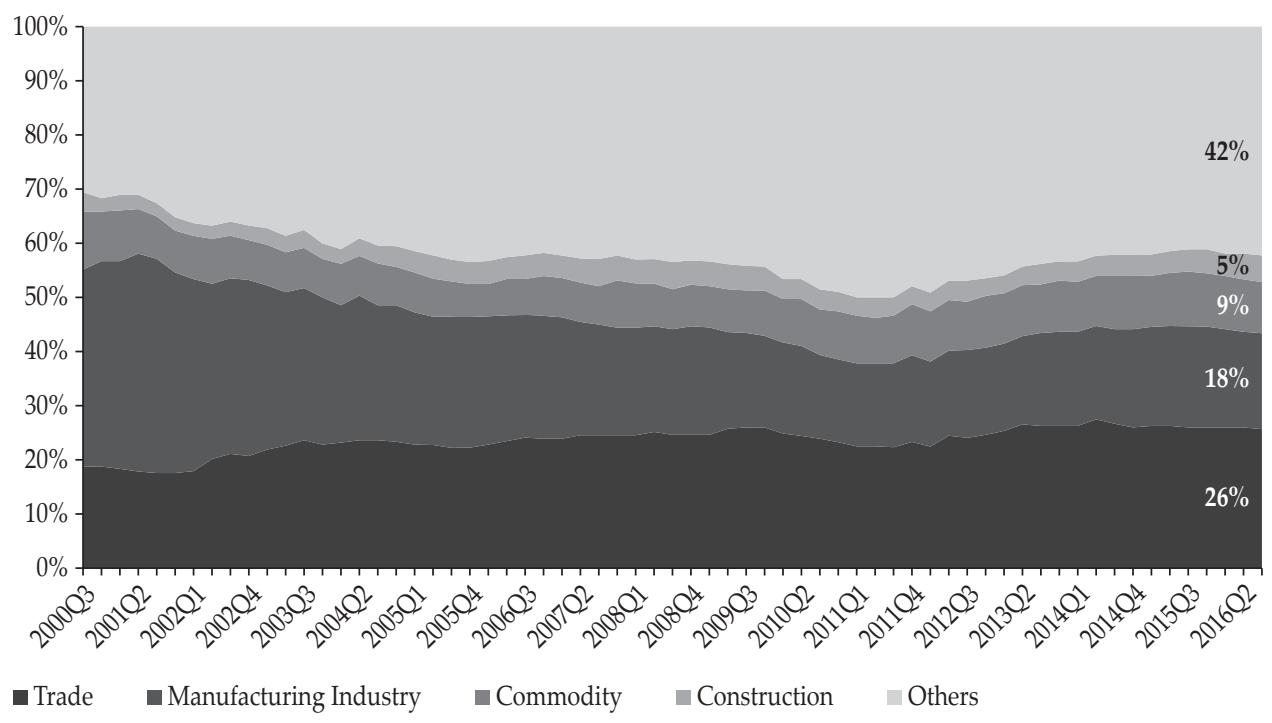

Graph 2. Credit Shares per Economic Sector to Total Credit

Across economic sector, the most significant decrease in credit growth was experienced by the manufacturing with credit share of $18 \%$ to the total credits. In fact, the credit growth in that sector grew slowly from $18.79 \%$ (yoy) in 2015Q3 to $-0.08 \%$ (yoy) in 2016Q3. Meanwhile, the sectoral credits with the most significant share $(42 \%)$, represented by the credit for other sector, grew from $8.46 \%$ in 2015Q3 to $9.31 \%$ in 2016 Q3 (Graph 3).

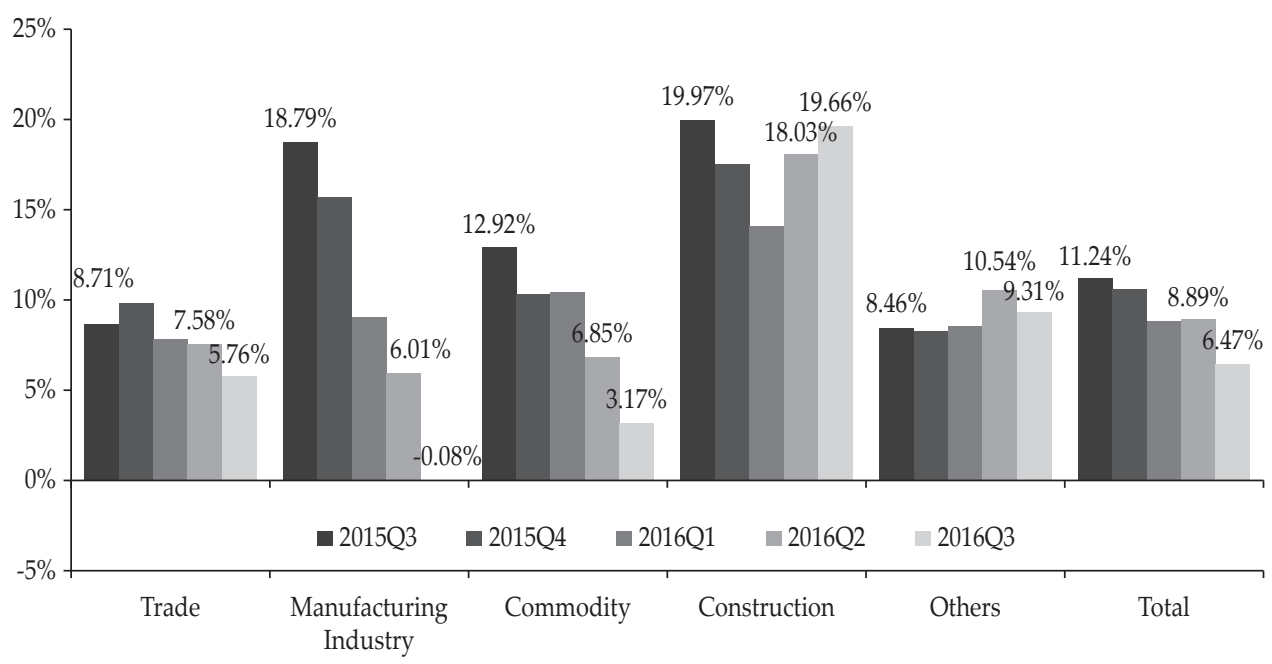

Graph 3. Credit Growth per Economic Sector 
Despite the ongoing credit risk rising trend in the second semester of 2016, the nonperforming loan growth was decelerated. The decrease of corporation performance and the slowdown of the credit growth lead to the rising trend of the credit risk (Bank Indonesia, 2017). Historically, around 2000-2007, the highest NPL was in the manufacturing sector. In the past few years, the NPL of the trade and services sectors was rise and had the highest NPLs (Graph 4).

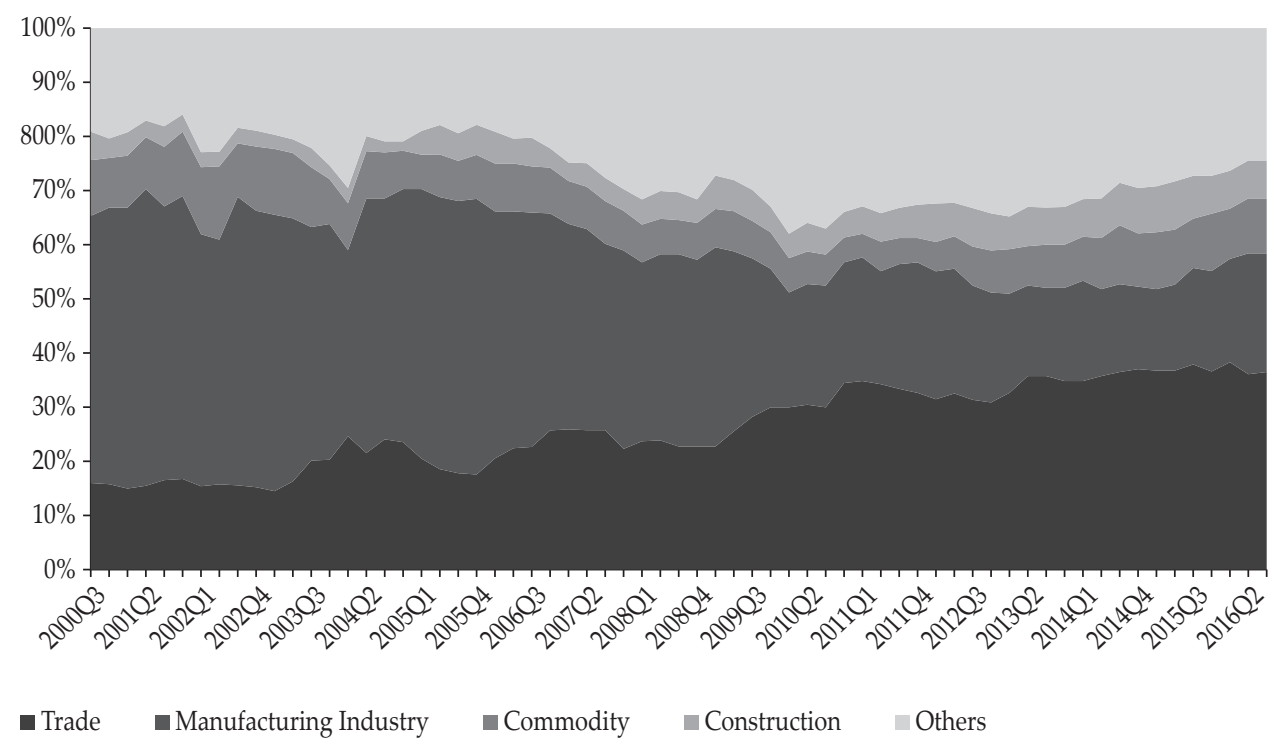

Graph 4. NPL shares per Economic Sector to Total NPL

Based on the 2016Q3 credit data, the highest NPL was in trading and services sectors with a ratio of $4.37 \%$, followed by construction sector $(4.26 \%)$, manufacturing sector (3.88\%), commodity sector (3.36\%), and other sectors $(1.8 \%)$ These NPL ratio is calculated from the total credit for each sector (Graph 5). 


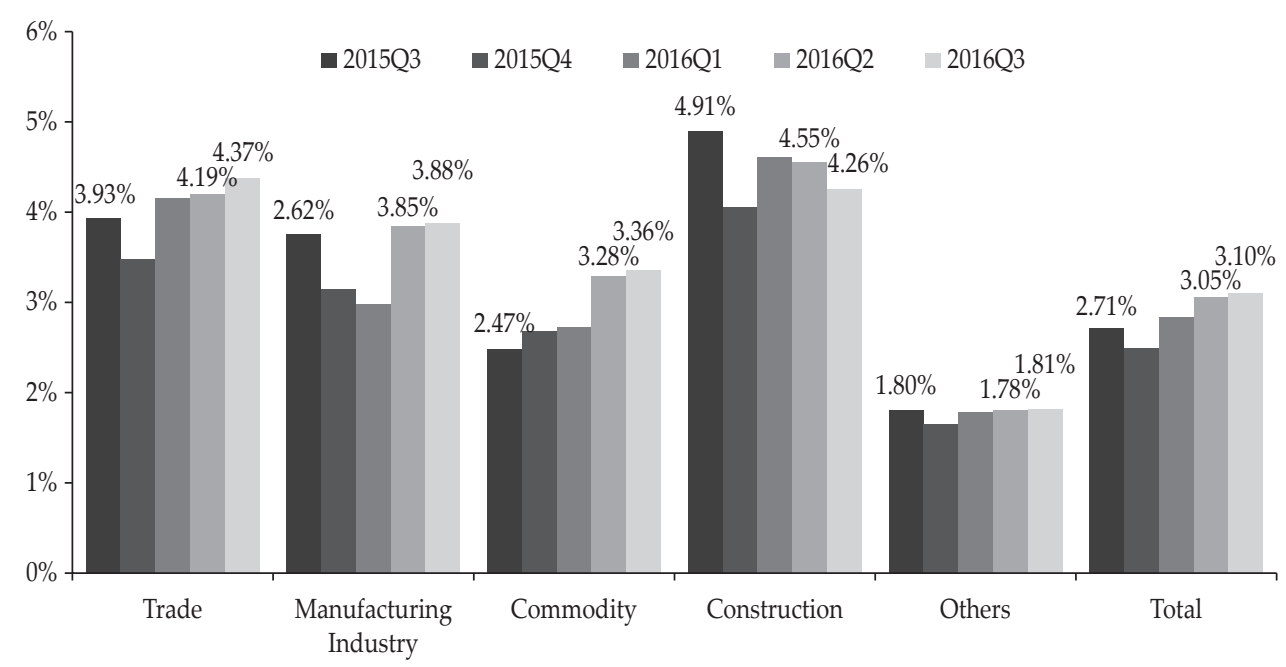

Graph 5. NPL Ratio per Economic Sector

When compared with the NPL data in the 2015Q3, the manufacturing sector recorded a significant increase in credit risks during the 2016Q3. The NPL of this sector was recorded at 3.88\% and higher compared to that of the 2015Q3 $(2.62 \%)$ (Graph 5).

\subsection{Literature Review}

As mentioned earlier, there are at least three approaches that can be used to assess credit risk in the banking industry. The first approach is to model Nonperforming Loan ratio (NPL) using macroeconomic variables as determinants. On the second approach, credit risks are estimated using probability of default, i.e evaluate transition matrix of performing loan into nonperforming loan for each bank. The third approach is to model bank's provision without computing bank's NPL.

From those approaches, the nonperforming loan model is the most commonly used to determine the impact of macroeconomic conditions on banking risk. Compared to the other two alternatives, the first approach also has higher dataside flexibility as it can be modeled at the aggregate level (total credit) as well as at a more granular level - by types of credit allocation or economic sector.

There are several studies that analyzed the relationship between credit risk and macroeconomic variables. At the aggregate level, Vatansever and Hepsen (2013) examined the long-term relationship between NPL ratio with macroeconomic indicators and banking variables by using cointegration and linear regression analysis. The research cover the monthly Turkish data for the period between January 2007 and March 2013. Vatansever and Hepsen found that the NPL ratio was negatively affected by the industrial production index, the Istanbul Stock Exchange 100 Index, and the bank's inefficiency ratio. While the unemployment rate, Return on Equity (ROE), and Capital Adequacy Ratio (CAR) positively affected the NPL ratio. 
Nkusu (2011) analyzed the determinant of NPL ratio by using the dynamic data panel for aggregate banking data in 26 advanced countries with annual periods from 1998 to 2009. Nkusu found that macroeconomic variables such as economic growth contraction (Real GDP), rising unemployment rate, high-interest rates, falling equity prices and falling housing prices will lead to an increase in the NPLs. He also added a Panel Vector Autoregressive (PVAR) analysis to estimate the feedback between the NPL ratio and its macroeconomic determinants.

Furthermore, Buncic and Melecky (2012) conducted an analysis of dynamic data panels (unbalanced) with the GMM (Arellano Bond estimator) method at the banking aggregate level in 54 high and middle-income countries for the annual period from 1994 to 2004 . They found that the real GDP growth, inflation, and real interest rates are significant variables in influencing the NPL ratio. The control variables included the credit to GDP ratio and the share of FX loans in total loans, and the change in the nominal US dollar exchange rate for each country, which do not significantly affect the ratio of NPL.

By using a dynamic data panel analysis for banking aggregate data in 9 countries, in Central, Eastern, and Southeastern European (CESEE) within the period from the 2004Q1 to the 2012Q4, Jakubik and Reininger (2013) modeled the relationship of macroeconomic variables with NPL ratio. The approach applied in this research was the Difference Generalized Linear Model (GMM) and System GMM in order to evade problems of correlation between the explanatory variables and the error term and to obtain additional efficiency gains. Jakubik and Reininger found that the growth of real gross domestic product (first lag) and the national stock price index (fifth lag) had a negative effect to the NPL ratio. On the other hand, the exchange rate weighted by foreign currency share (first lag) and private sector-credit-to-GDP ratio (sixth lag) had a positive relationship with the NPL ratio.

Klein (2013) analyzed the determinants of the NPL ratio with individual bank data panels covering the top 10 largest banks in each of the CESEE countries within the annual period from 1998 to 2011. Klein consider three alternative estimation techniques including the fixed effects model, difference GMM, and system GMM. Klein stated that NPLs are indeed influenced by both macroeconomic variables and bank-specific factors, although the power of bank-specific factors as explanatory variables was found to be low. In his research, the increase in NPL was influenced by macroeconomic conditions such as declining real GDP growth, higher unemployment rate, higher inflation, exchange rate depreciation, and higher volatility index. While banking indicators such as increasing equityto-assets ratio, increasing $\mathrm{ROE}$, decreasing the loan-to-assets ratio and declining credit growth leads to lower the NPLs.

The global sample of 75 countries in the world was used by Beck (2015) to analyze the determinants of NPLs. His research used static and dynamic panel data estimation through fixed effects model and GMM method. The results revealed that the real GDP growth variables, share prices, the exchange rate, and lending interest rates significantly affect the NPL.

Curak et al. (2013) investigates the determinants of NPLs in 10 Southeastern European countries. The analysis is based on sample of 69 individual banks data in the annual period from 2003 to 2010 using GMM estimator for dynamic panel 
data models. The results show that lower economic growth, higher inflation, and higher interest rate are associated with higher NPLs. Additionally, bank-specific factors such as bank size, performance (ROA), and solvency levels, measured by capital to total assets ratio, also affect the credit risk.

Beaton et al. (2016) estimates the determinants of NPLs by using bank level panel data of all domestic and foreign banks in Eastern Carribean Currency Union (ECCU). The sample includes 34 banks in 6 ECCU countries for the period from 1996Q1 to 2015Q4. The data are aggregated by individual bank. This research used dynamic panel regression with three alternative estimation techniques such as fixed effects, random effects, and GMM with instrumental variables. The results suggesting that stronger economic growth in advanced economies lowers NPLs in the ECCU. This result is consistent with the characteristics of the ECCU member countries which are small and open economies. Tourism growth as a proxy for domestic economic activity will potentially increase the NPLs. Bank specific factors such as higher bank profitability captured by Return on Assets (ROA) is found to lower NPLs, while bank's lending portfolios in loans to household and construction have potential to increase NPLs.

For the Indonesian case, Firmansyah (2014) analyzed the nonperforming loan and its determinant using the monthly data Islamic banks during 2010 through 2012. The data obtained was averaged data for all Islamic bank in Indonesia and estimated using linear regression. The research showed that size and efficiency of the banks do not affect the NPLs while both GDP and inflation negatively affect the NPLs.

Using the Regional Development Bank (RDB) panel data, Alexandri and Santoso (2015) conducted a determinant analysis on the NPL ratio to 26 RDB in Indonesia. The research used panel data regression analysis with random effects model for the sample period from 2009 to 2013. While using the sample period between the 2012Q1 and the 2015Q4, Sari et al. (2015) analyzed the NPL ratio determinants for 25 RDB with fixed effect model. Alexandri and Santoso stated that the level of bank efficiency, represented by the ROA, has a positive and significant impact on the NPL. While the variable bank size, GDP growth, CAR, and the rate of inflation did not significantly affect the NPL. Similarly, Sari et al. stated that the ROE, bank size, and credit growth had a negative impact on NPL, while bank efficiency, represented by operational cost to operating income ratio, had a positive effect on the NPL ratio. Macroeconomic variables such as exchange rate and GDP growth have a significant impact. Exchange rate has a positive effect on NPL, while GDP growth has negative effect on NPL.

Surjaningsih et al. (2016) built a credit risk model using credit risk disaggregation based on types of credit allocation (consumer and productive loans) and types of currency (rupiah and foreign currency). Estimations were performed using individual data of 118 commercial banks for the period between 2001Q1 through 2015Q1. The credit risk model uses the NPL ratio to total credits based on types of credit allocation as dependent variables and macroeconomic variables as independent variables, which includes the quarterly real GDP growth rate, the squares of the quarterly real GDP growth rate, change in the nominal BI policy rate (quarterly), and the change in nominal effective exchange rate (quarterly). The estimation results showed that the sensitivity of the NPL ratio to changes in 
macroeconomic conditions varies significantly between the borrower types. The NPL ratio of productive loans is more sensitive to changes in macroeconomic conditions compared to consumer loans.

Surjaningsih et al. (2016) also conducted a study on the determinant analysis of NPL ratio that focused on macroeconomic variables as the primary driver. Besides the data period that used, the difference is the disaggregation of credit risk that grouped into five different economic sectors.

\section{METHODOLOGY}

\subsection{Methodology}

To model each bank's credit risk for five major economic sectors, as a result of macroeconomic condition, we utilized dynamic panel data models of 117 commercial banks in Indonesia. Two approaches were used to model credit risks: fixed effect autoregressive distributed lag and system generalized method of moment. The models follow previous model developed by Buncic and Melecky (2012), Klein (2013), Beaton et al. (2016), and Surjaningsih et al. (2016).

\section{Fixed Effect - Autoregressive-Distributed Lag}

The first approach used to estimate credit risk is the dynamic panel data with fixed effect and autoregressive distributed lag which has the following general representation:

$$
L N P L_{i, t}=\mu_{i}+\alpha_{1} L N P L_{i, t-1}+\alpha_{2} L N P L_{i, t-2}+C(L) \cdot M A C R O_{t}+\varepsilon_{i, t}
$$

Where the index $i$ indicates individual banking institution and $t$ indicates quarterly time period. $L N P L_{i, t}$ denotes the logit transformation of the NPL ratio that can be expressed as:

$L N P L_{i, t}=\ln \left(\frac{N P L_{i, t}}{1-N P L_{i, t}}\right)$

The vector $M A C R O_{t}$ denotes a set of macroeconomic explanatory variables that affect the NPL, $\mu_{i}$ represent bank specific fixed effects, and $\varepsilon_{i, t}$ represents error term. $C(L)$ denotes lag polynomials taking general form

$C(L)=c_{o}+c_{1} \cdot L+c_{2} \cdot L^{2}+c_{3} \cdot L^{3}+\cdots$

Our study did not explicitly use internal banking variables as control variables but we incorporate lags from NPL as the independent variables. Our study focused on the macroeconomic impact on bank credit risk. 
Panel data model contain one or more lagged dependent variables can produce a biased estimation because the strict exogenous characteristics of the regressor is no longer met. This bias is commonly known as Nickell's bias (1981) ${ }^{3}$. Nickell bias occurs when $\mathrm{T}$ is small, and $\mathrm{N}$ is significant due to the demeaning process which can cause correlation between error and independent variable. However, when the $\mathrm{T}$ is large enough, fixed panel data approach still produces consistent estimators.

Since the individual characteristics of each bank are important parameters to be analyzed in this study, the fixed effect approach will be the primary analysis and Arellano and Bond approaches (1991) System Generalized Methods of Moments (GMM) will be the additional analysis as the robustness check.

\section{System Generalized Method of Moments (GMM)}

The dynamic approach is adapted to take into account the persistence of time within the credit risk structure. The model is written as the following equation:

$$
L N P L_{i, t}=\alpha+\sum_{j=1}^{J} \gamma_{j} L N P L_{i, t-j}+\mathbb{x}_{i, t} \beta+\varepsilon_{i, t}
$$

With $\mathrm{i}=1, \ldots, \mathrm{N}$ and $\mathrm{t}=1, \ldots, \mathrm{T}$ denoting the dimension of cross section and time in panel data. $\alpha$ indicates the common intercept, $\mathbb{x}_{i, t}$ denotes the independent variable vector of $k \times 1, \beta$ represents the vector coefficient of $k \times 1$, and $\varepsilon_{i, t}$ represents an error term.

Judson and Owen (1999) stated that, for a sample of data with a length of $t \leq 30$, the bias in the results could reach $20 \%$ from the actual estimator value. The problem can be solved by using the first-difference equation. This approach eliminates individual effects as well as the accompanying bias.

$\Delta L N P L_{i, t}=\alpha+\sum_{j=1}^{J} \gamma_{j} \Delta L N P L_{i, t-j}+\Delta \mathbb{x}_{i, t} \beta+\Delta \varepsilon_{i, t}$

Another alternative method (also known as Difference GMM) is using the System GMM. The System GMM estimator adds restriction to the instrument variable in the model. The instrument variables are then tested for validity by using Sargan and Hausman test.

\subsection{Data}

Data used for credit risk model were the ratio of NPL that have been grouped by types of credit per major sector in Indonesia: (i) commodity sector (including agriculture and mining); (ii) trade and service; (iii) manufacturing industry; (iv) construction (property and real estate); and (v) other sectors. Data cover 117 commercial banks consist of 104 conventional banks and 13 islamic banks during 2000 Q1 until 2016 Q3 (source: Bank Indonesia).

3 Nickell, S. (1981). Biases in Dynamic Models with Fixed Effects, Econometrica, 49, 1399-1416. 
NPL ratio as the dependent variable was transformed using logarithmic transformation as stated on equation (2). This transformation not only ensures that the dependent variable spans over $-\infty$ and $+\infty$ (instead of between 0 and 1 ) but also ensures that NPL ratio symmetrically distributed. In reality, several banks might have NPL ratio equal to 0 in some period, this could be happen if banks own zero NPL or zero lending to a particular sector during a particular period. As a result, the logarithmic transformation becomes undefined. To overcome the problem we can replace the NPL ratio that equal to 0 into empty value, alternatively we can change NPL ratio value into small number near $0\left(\right.$ e.g. $\left.10^{-6}\right)$. The drawback of the second approach is that the predicted value of NPL might inaccurate.

Macroeconomic explanatory variables in $M A C R O_{t}$ is describe in Table 1. Quarterly real GDP growth rate - seasonally adjusted ( $\left.r g d p s a \_q\right)$ is expected to have an inverse relationship with NPL ratio. NPL ratio increases as real GDP growth declines and vice versa. Attempt to include GDP per sector terms in order to capture stronger relationship to credit risk is proved futile. This might be because share of lending per sector and share of GDP per sector was not comparable. Changes in policy rate (chpolrate) have a direct impact on the debitor repayment ability which affect NPLs. Quarterly house price inflation $\left(h p \_q\right)$ affects NPLs through debitor wealth (wealth effect) meanwhile quarterly commodity price inflation (comp_q) not only capture external risks but also expected to capture other specific factors. All macroeconomic data span from 2000Q1 until 2016Q3.

Table 1.

Macroeconomic Variable Determinants of Credit Risks

\begin{tabular}{|c|c|c|}
\hline Variable & Description & Source \\
\hline rgdpsa_q & Real GDP growth rate that has been seasonally adjusted, quarterly & $\mathrm{BI}$ \\
\hline chpolrate & Quarter-on-quarter change in the nominal BI policy rate & $\mathrm{BI}$ \\
\hline nexr_q & $\begin{array}{l}\text { Quarter-on-quarter rate of change in the nominal exchange rate, a positive } \\
\text { value indicates an appreciation of the Rupiah }\end{array}$ & BI \\
\hline hp_q & Quarterly growth in house prices (house price inflation rate) & BI \\
\hline comp_q & Quarterly growth in commodity price (commodity price inflation rate) & $\mathrm{BI}$ \\
\hline
\end{tabular}

\section{RESULTS AND ANALYSIS}

\subsection{Fixed Effect Panel Data Estimation}

The empirical results for fixed effect regressions corresponding to different types of credit exposures (excluding fixed effect coefficients estimates) are presented in Table 2. Based on characteristics and behavior of credit risk in Indonesia, a credit quality (payment collectability status) from current and special mention does not automatically turn into NPLs within one quarter. Therefore, our analysis takes into account two lags (two quarters) of the NPL ratio as an explanatory variables. On the other hand, four lags of macroeconomic variables are used since macroeconomic variables affect credit quality in longer period.

In general, most of the explanatory variables have a significance level above $10 \%$ either individually or jointly in the joint t-test (Appendix) except the policy rate in the construction sector. All macroeconomic determinants have the expected 
effect on NPL ratios. Real economic growth is the main driver that is negatively correlated with credit risks in all sectors. Increased in real economic growth will positively affect business activities so that the sustainability of credit payment is maintained. The inverse relation is also found in commodity and housing price. Commodity price inflation affects NPL in manufacturing industry and trade sectors, meanwhile housing price inflation influences NPL in manufacturing industry, trade, and construction sectors. In addition, decreased in policy rate will decline credit risk in commodity, trade, and other sectors, meanwhile nominal exchange rate only affects credit risks in other sector. We take into account dummy structural break (2010Q3 through 2016Q3) for credit risk model in construction sector.

Table 2.

Fixed Effect Panel Data (FE) Estimation Results

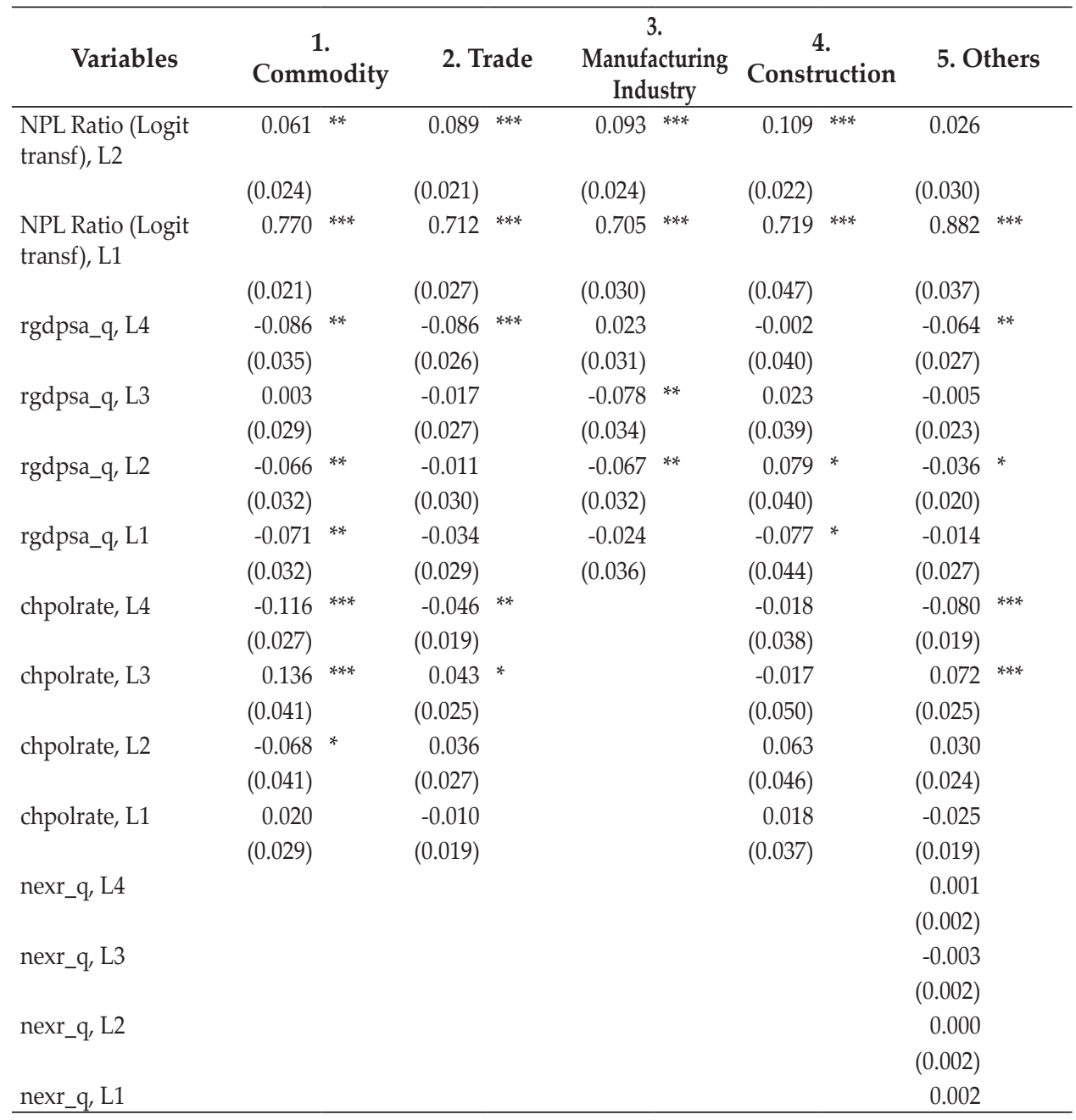


Table 2.

Fixed Effect Panel Data (FE) Estimation Results (Continued)

\begin{tabular}{|c|c|c|c|c|c|}
\hline Variables & $\begin{array}{c}1 . \\
\text { Commodity }\end{array}$ & 2. Trade & $\begin{array}{c}3 . \\
\text { Manufacturing } \\
\text { Industry }\end{array}$ & $\begin{array}{c}4 . \\
\text { Construction }\end{array}$ & 5. Others \\
\hline \multirow[t]{2}{*}{ hp_q, L4 } & & 0.018 & 0.004 & $0.074^{* * *}$ & \\
\hline & & $(0.012)$ & $(0.012)$ & $(0.019)$ & \\
\hline \multirow[t]{2}{*}{ hp_q, L3 } & & $-0.030 * *$ & $-0.028 * *$ & -0.032 & \\
\hline & & $(0.012)$ & $(0.012)$ & $(0.020)$ & \\
\hline \multirow[t]{2}{*}{ hp_q, L2 } & & -0.009 & 0.018 & $-0.044^{* *}$ & \\
\hline & & $(0.014)$ & $(0.014)$ & $(0.021)$ & \\
\hline \multirow[t]{2}{*}{ hp_q, L1 } & & -0.004 & $-0.067^{* * *}$ & -0.021 & \\
\hline & & $(0.011)$ & $(0.015)$ & $(0.023)$ & \\
\hline \multirow[t]{2}{*}{ comp_q, L4 } & & -0.001 & 0.002 & & 0.001 \\
\hline & & $(0.001)$ & $(0.001)$ & & $(0.001)$ \\
\hline \multirow[t]{2}{*}{ comp_q, L3 } & & 0.000 & $0.002 *$ & & 0.000 \\
\hline & & $(0.001)$ & $(0.001)$ & & $(0.001)$ \\
\hline \multirow[t]{2}{*}{ comp_q, L2 } & & $-0.003 * * *$ & -0.001 & & $-0.002 *$ \\
\hline & & $(0.001)$ & $(0.001)$ & & $(0.001)$ \\
\hline \multirow[t]{2}{*}{ comp_q, L1 } & & 0.000 & 0.000 & & 0.002 \\
\hline & & $(0.001)$ & $(0.001)$ & & $(0.002)$ \\
\hline Dummy & & & & $\begin{array}{r}-0.054 \\
(0.039)\end{array}$ & \\
\hline $\begin{array}{l}\text { Common intercept } \\
\text { term }\end{array}$ & $\begin{array}{l}-0.223 \quad * * * \\
(0.103)\end{array}$ & $\begin{array}{l}-0.414 \\
(0.109)\end{array}$ & $\begin{array}{l}-0.395 \quad * * * \\
(0.119)\end{array}$ & $\begin{array}{l}-0.534 \\
(0.120)\end{array}$ & $\begin{array}{l}-0.259 \\
(0.164)\end{array}$ \\
\hline Total Observations & 4076 & 5279 & 4903 & 3662 & 6390 \\
\hline Total Groups & 107 & 114 & 115 & 107 & 115 \\
\hline R-squared (within) & 0.684 & 0.625 & 0.625 & 0.621 & 0.681 \\
\hline R-squared (between) & 0.971 & 0.995 & 0.990 & 0.983 & 0.763 \\
\hline
\end{tabular}

Note: ${ }^{* * *}$ indicates significance at $1 \%,{ }^{* *}$ significance at $5 \%,{ }^{*}$ significance at $10 \%$. Number in brackets represent Std Error (Robust).

\subsection{Robustness Check}

As mentioned earlier, to test the robustness of the Fixed Effect model above we conduct GMM estimation as a comparison. The estimation results are presented in Table 3. 
Table 3.

Generalized Method of Moments (GMM estimation results)

\begin{tabular}{|c|c|c|c|c|c|c|c|c|c|c|}
\hline \multirow{2}{*}{\begin{tabular}{l}
\multicolumn{1}{c}{ Variables } \\
NPL Ratio (Logit \\
transf), L2
\end{tabular}} & \multicolumn{2}{|c|}{$\begin{array}{c}1 . \\
\text { Commodity }\end{array}$} & \multicolumn{2}{|c|}{ 2. Trade } & \multicolumn{2}{|c|}{$\begin{array}{c}3 . \\
\text { Manufacturing } \\
\text { Industry }\end{array}$} & \multicolumn{2}{|c|}{$\begin{array}{c}4 . \\
\text { Construction }\end{array}$} & \multicolumn{2}{|c|}{ 5. Others } \\
\hline & 0.052 & & 0.086 & $* * *$ & 0.067 & $*$ & 0.155 & $* * *$ & 0.046 & \\
\hline & $(0.034)$ & & $(0.031)$ & & $(0.034)$ & & $(0.040)$ & & $(0.029)$ & \\
\hline \multirow{2}{*}{$\begin{array}{l}\text { NPL Ratio (Logit } \\
\text { transf), L1 }\end{array}$} & 0.782 & $* * *$ & 0.724 & $* * *$ & 0.683 & $* * *$ & 0.782 & $* * *$ & 0.921 & $* * *$ \\
\hline & $(0.032)$ & & $(0.037)$ & & $(0.034)$ & & $(0.051)$ & & $(0.036)$ & \\
\hline \multirow[t]{2}{*}{ Rgdpsa_q, L4 } & -0.053 & & -0.065 & $* *$ & 0.008 & & 0.002 & & -0.034 & \\
\hline & $(0.035)$ & & $(0.027)$ & & $(0.035)$ & & $(0.046)$ & & $(0.025)$ & \\
\hline \multirow[t]{2}{*}{ Rgdpsa_q, L3 } & 0.002 & & -0.008 & & -0.091 & $* *$ & 0.036 & & 0.024 & \\
\hline & $(0.033)$ & & $(0.028)$ & & $(0.037)$ & & $(0.039)$ & & $(0.026)$ & \\
\hline \multirow[t]{2}{*}{ Rgdpsa_q, L2 } & -0.072 & ** & -0.013 & & -0.082 & $* * *$ & 0.081 & $* *$ & -0.018 & \\
\hline & $(0.036)$ & & $(0.029)$ & & $(0.032)$ & & $(0.039)$ & & $(0.020)$ & \\
\hline \multirow[t]{2}{*}{ Rgdpsa_q, L1 } & -0.050 & & -0.033 & & -0.026 & & -0.058 & & 0.016 & \\
\hline & $(0.033)$ & & $(0.030)$ & & $(0.036)$ & & $(0.043)$ & & $(0.023)$ & \\
\hline \multirow[t]{2}{*}{ Chpolrate, L4 } & -0.120 & $* * *$ & -0.049 & $* *$ & & & -0.042 & & -0.082 & $* * *$ \\
\hline & $(0.028)$ & & $(0.021)$ & & & & $(0.034)$ & & $(0.019)$ & \\
\hline \multirow[t]{2}{*}{ Chpolrate, L3 } & 0.145 & $* * *$ & 0.050 & * & & & -0.008 & & 0.083 & $* * *$ \\
\hline & $(0.041)$ & & $(0.026)$ & & & & $(0.047)$ & & $(0.024)$ & \\
\hline \multirow[t]{2}{*}{ Chpolrate, L2 } & -0.086 & & 0.023 & & & & 0.061 & & 0.009 & \\
\hline & $(0.043)$ & & $(0.026)$ & & & & $(0.048)$ & & $(0.022)$ & \\
\hline \multirow[t]{2}{*}{ Chpolrate, L1 } & 0.032 & & -0.010 & & & & 0.046 & & -0.011 & \\
\hline & $(0.028)$ & & $(0.017)$ & & & & $(0.041)$ & & $(0.020)$ & \\
\hline \multirow[t]{2}{*}{ Nexr_q, L4 } & & & & & & & & & 0.000 & \\
\hline & & & & & & & & & $(0.002)$ & \\
\hline \multirow[t]{2}{*}{ Nexr_q, L3 } & & & & & & & & & -0.004 & \\
\hline & & & & & & & & & $(0.002)$ & \\
\hline \multirow[t]{2}{*}{ Nexr_q, L2 } & & & & & & & & & -0.001 & \\
\hline & & & & & & & & & $(0.003)$ & \\
\hline \multirow[t]{2}{*}{ Nexr_q, L1 } & & & & & & & & & 0.002 & \\
\hline & & & & & & & & & $(0.003)$ & \\
\hline \multirow[t]{2}{*}{ Hp_q, L4 } & & & 0.015 & & 0.007 & & 0.097 & $* * *$ & & \\
\hline & & & $(0.014)$ & & $(0.012)$ & & $(0.021)$ & & & \\
\hline \multirow[t]{2}{*}{ Hp_q, L3 } & & & -0.025 & $* *$ & -0.029 & $* *$ & -0.011 & & & \\
\hline & & & $(0.012)$ & & $(0.014)$ & & $(0.021)$ & & & \\
\hline \multirow[t]{2}{*}{ Hp_q, L2 } & & & -0.013 & & 0.009 & & -0.041 & * & & \\
\hline & & & $(0.015)$ & & $(0.016)$ & & $(0.022)$ & & & \\
\hline \multirow[t]{2}{*}{ Hp_q, L1 } & & & -0.005 & & -0.075 & $* * *$ & -0.017 & & & \\
\hline & & & $(0.010)$ & & $(0.015)$ & & $(0.029)$ & & & \\
\hline Comp_q, L4 & & & -0.001 & & 0.002 & & & & 0.001 & \\
\hline & & & $(0.001)$ & & $(0.001)$ & & & & $(0.001)$ & \\
\hline Comp_q, L3 & & & 0.000 & & 0.003 & * & & & -0.002 & \\
\hline & & & $(0.001)$ & & $(0.001)$ & & & & $(0.001)$ & \\
\hline
\end{tabular}


Table 3.

Generalized Method of Moments (GMM estimation results) (Continued)

\begin{tabular}{|c|c|c|c|c|c|}
\hline Variables & $\begin{array}{c}1 . \\
\text { Commodity }\end{array}$ & 2. Trade & $\begin{array}{c}. \\
\text { Manufacturing } \\
\text { Industry }\end{array}$ & $\begin{array}{c}4 . \\
\text { Construction }\end{array}$ & 5. Others \\
\hline Comp_q, L2 & & $\begin{array}{l}-0.002 * \\
(0.001)\end{array}$ & $\begin{array}{r}-0.001 \\
(0.001)\end{array}$ & & $\begin{array}{l}-0.0022^{* *} \\
(0.001)\end{array}$ \\
\hline Comp_q, L1 & & $\begin{array}{r}0.000 \\
(0.001)\end{array}$ & $\begin{array}{r}0.000 \\
(0.001)\end{array}$ & & $\begin{array}{r}0.001 \\
(0.001)\end{array}$ \\
\hline Dummy & & & & $\begin{array}{l}-0.154 * \\
(0.081)\end{array}$ & \\
\hline $\begin{array}{l}\text { Common intercept } \\
\text { term }\end{array}$ & $\begin{array}{l}-0.276^{* *} \\
(0.139)\end{array}$ & $\begin{array}{l}-0.417{ }^{* * *} \\
(0.163)\end{array}$ & $\begin{array}{l}-0.4688^{* * *} \\
(0.150)\end{array}$ & $\begin{array}{r}-0.249 \\
(0.190)\end{array}$ & $\begin{array}{r}-0.149 \\
(0.113) \\
\end{array}$ \\
\hline Total observations & 4076 & 5279 & 4903 & 3662 & 6390 \\
\hline Total groups & 107 & 114 & 115 & 107 & 115 \\
\hline Total Instruments & 134 & 124 & 120 & 120 & 142 \\
\hline Hansen test $\mathrm{p}$-value & 0.937 & 0.464 & 0.404 & 0.827 & 0.844 \\
\hline $\begin{array}{l}\text { A-B AR(1) test } \\
\text { p-value }\end{array}$ & 0.000 & 0.000 & 0.000 & 0.000 & 0.005 \\
\hline $\begin{array}{l}\text { A-B AR(2) test } \\
\text { p-value }\end{array}$ & 0.370 & 0.419 & 0.775 & 0.029 & 0.544 \\
\hline
\end{tabular}

Note: ${ }^{* * *}$ indicates significance at $1 \%,{ }^{* *}$ significance at $5 \%,{ }^{*}$ significance at $10 \%$. Number in brackets represent Std Error (Robust).

In general, most of the explanatory variables significance at least at $10 \%$ confidence level either individually or collectively in the joint t-test (Appendix 1). The results of the GMM method confirmed those of the fixed panel data estimation. Furthermore, the results of Sargan and Hansen test (in Table 3) confirmed the validation of the model used. Thus, it can be concluded that the equation generated by the panel fixed effect was robust enough.

\subsection{Elasticities}

Elasticities indicated how NPL ratios would change in the long run if macroeconomic determinants changed in permanent basis. Equation (1) can be rewritten specifically according to model provided in Chapter 4.1 as follows:

$$
\begin{aligned}
& L N P L_{i, t}=\mu_{i}+\lambda_{1} \cdot L N P L_{i, t-1}+\lambda_{2} \cdot L N P L_{i, t-2}+\alpha_{1} \cdot r g d p s a_{-} q_{i, t-1} \\
& +\alpha_{2} \cdot r g d p s a_{-} q_{i, t-2}+\alpha_{3} \cdot r g d p s a_{-} q_{i, t-3}+\alpha_{4} \cdot r g d p s a_{-} q_{i, t-4} \\
& +\beta_{1} \text {. } \text { pholrate }{ }_{i, t-1}+\beta_{2} \text {. } \text { chpolrate }_{i, t-2} \\
& +\beta_{3} \text {. } \text { chpolrate }_{i, t-3}+\beta_{4} \text {. } \text { chpolrate }_{i, t-4}+\gamma_{1} \text {. nexr_ } q_{i, t-1} \\
& +\gamma_{2} \text {.nexr_q } q_{i, t-2}+\gamma_{3} . \text { nexr_q } q_{i, t-3}+\gamma_{4} \cdot \text { nexr_ } q_{i, t-4} \\
& +\delta_{1} \cdot h p_{-} q_{i, t-1}+\delta_{2} \cdot h p_{-} q_{i, t-2}+\delta_{3} \cdot h p_{-} q_{i, t-3}+\delta_{4 \cdot} \cdot h p_{-} q_{i, t-4} \\
& +\theta_{1} \cdot \text { comp_ }_{i, t-1}+\theta_{2} \cdot{ }_{\text {comp_ }} q_{i, t-2}+\theta_{3} \cdot \text { comp_ }_{i, t-3} \\
& +\theta_{4} \cdot \text { comp_ }_{i, t-4}+\varepsilon_{i, t}
\end{aligned}
$$


The (long-term) elasticity of the NPL ratio with respect to a one percentage increase in real GDP Growth (rgdpsa_q), change in the policy rate (chpolrate), exchange rate growth (nexr_q), house price inflation (hp_q), and commodity price inflation (comp_q) can be calculated with formulas from (7) to (11) as follows:

$$
\begin{aligned}
& \frac{\partial L N P L_{i, \infty}}{\partial r g d p s a_{-} q}=\left(\sum_{j=1}^{4} \alpha_{j}\right) \cdot\left(L N P L_{i, t}\right) \cdot\left(1-L N P L_{i, t}\right) \cdot\left(\frac{1}{1-\lambda_{1}-\lambda_{2}}\right) \\
& \frac{\partial L N P L_{i, \infty}}{\partial \text { chpolrate }}=\left(\sum_{j=1}^{4} \beta_{j}\right) \cdot\left(L N P L_{i, t}\right) \cdot\left(1-L N P L_{i, t}\right) \cdot\left(\frac{1}{1-\lambda_{1}-\lambda_{2}}\right) \\
& \frac{\partial L N P L_{i, \infty}}{\partial \text { dexr }_{-}}=\left(\sum_{j=1}^{4} \gamma_{j}\right) \cdot\left(L N P L_{i, t}\right) \cdot\left(1-L N P L_{i, t}\right) \cdot\left(\frac{1}{1-\lambda_{1}-\lambda_{2}}\right) \\
& \frac{\partial L N P L_{i, \infty}}{\partial h p_{-} q}=\left(\sum_{j=1}^{4} \delta_{j}\right) \cdot\left(L N P L_{i, t}\right) \cdot\left(1-L N P L_{i, t}\right) \cdot\left(\frac{1}{1-\lambda_{1}-\lambda_{2}}\right) \\
& \frac{\partial L N P L_{i, \infty}}{\partial \text { comp }_{-} q}=\left(\sum_{j=1}^{4} \theta_{j}\right) \cdot\left(L N P L_{i, t}\right) \cdot\left(1-L N P L_{i, t}\right) \cdot\left(\frac{1}{1-\lambda_{1}-\lambda_{2}}\right)
\end{aligned}
$$

\begin{tabular}{|c|c|c|c|c|c|}
\hline & $\begin{array}{c}1 . \\
\text { Commodity }\end{array}$ & 2. Trade & $\begin{array}{c}3 . \\
\text { Manufacturing } \\
\text { Industry }\end{array}$ & $\begin{array}{c}4 . \\
\text { Construction }\end{array}$ & 5. Others \\
\hline \multicolumn{6}{|c|}{ Long run elasticity with respect to a one percentage point (permanent) change in quarterly rates of: } \\
\hline Rgdpsa_q & -0.062 & -0.035 & -0.034 & 0.006 & -0.061 \\
\hline Chpolrate & -0.008 & 0.005 & & 0.013 & -0.002 \\
\hline Nexr_q & & & & & -0.001 \\
\hline Comp_q & & -0.006 & -0.017 & -0.006 & \\
\hline Hp_q & & -0.001 & 0.001 & & 0.001 \\
\hline
\end{tabular}

The elasticities of NPL ratios with respect to changes in macroeconomic variable for each sector are presented in Table 4.

Table 4.

Elasticites of NPL Ratios with Respect to Changes in Macroeconomic Variables

From Table 4, the elasticities indicate how NPL ratio would change in the long run if the quarterly rates of the macroeconomic determinants increased by one percentage point on a permanent basis. A permanent one percentage point (pp) increase in real GDP growth (equivalent to $4 \mathrm{pp}$ in an annual basis) would reduce the NPL ratio in the commodity sector by $0.062 \mathrm{pp}, 0.035 \mathrm{pp}$ in the trade sector, $0.034 \mathrm{pp}$ in the manufacturing sector, and 0.061 in the other sectors, and will increase the NPL ratio in the construction sector by $0.006 \mathrm{pp}$. 
Our assessment shows that credit risks in commodity and other sectors are more sensitive to real economic growth than those on manufacturing industry and trade sectors. Real economic growth elasticities to credit risk for commodity and other sectors are almost twice higher than for manufacturing industry and trade sectors. Thus, during economic contraction phase, NPL in commodity and other sectors will increase higher than NPL in manufacturing industry and trade sectors.

\section{CONCLUSION}

Previous researchs focused on how macroeconomic shocks impact the credit risk in aggregated loan. If it estimated in more granular level, the impact of those shocks may vary for each sector of the economy. The shock of one particular macroeconomic variable may not necessarily affect all sectors and the magnitude of its impact will be significantly affected by the sensitivity of each sector.

This paper analyze Nonperforming Loan ratio to total credit (NPL), as a proxy for credit risk, for five major economic sectors by utilizing panel data of 117 commercial banks in Indonesia over period 2000Q1 to 2016Q3. Our empirical analysis shows that in general there is a close relationship between NPL and macroeconomic variables. The details are as follows:

a. Real economic growth is the main driver that is negatively correlated with credit risks in all sectors.

b. Several variables only affect the NPL in particular sector. Changed in the policy rate affects the credit risks in commodity, trade and services sectors, as well as other sectors. If policy rate declined, credit interest rate declined and credit risks decline and vice versa. The change in nominal exchange rate only affects the NPLs of other sectors. Commodity price inflation rate only affects the NPL of trade and manufacturing sectors, while house price inflation rate affects the NPL in three sectors, namely trade, manufacturing industry, and construction sectors. Both commodity price and house price inflation negatively affect the NPLs.

c. The NPL ratios corresponding to commodity and other sectors are more sensitive to real GDP growth slowdown than those corresponding to manufacturing industry and trade sectors. The real GDP growth elasticities of NPL ratios corresponding to commodity and other sectors are about twice as large as the ones corresponding to NPL ratios of manufacturing industry and trade sectors. Thus, during an economic contraction phase, NPLs of commodity and other sectors will increase higher than NPLs in manufacturing industry and trade sectors.

This study analyzed the credit risk by looking at the NPL ratio and its macroeconomic determinants. This credit risk model can be used as one of the credit risk stress testing tools to complement previous models. Future researches can be conducted using credit that are disaggregated which corresponds to its GDP per economic sector so that it would possible to add GDP per economic sector as the explanatory variable. Future research can be done by adding internal banking variables such as ROA, ROE, CAR, etc. as the determinant of NPL ratio. 


\section{REFERENCES}

Alexandri, M.B., Santoso, T.I. (2015). Non Performing Loan: Impact of Internal and External Factor (Evidence in Indonesia). International Journal of Humanities and Social Science Invention, Volume 4 Issue 1. January 2015.

Arellano, M. and Bond, S. (1991). Some Tests of Specification for Panel Data: Monte Carlo Evidence and an Application to Employment Equations. Review of Economic Studies, 5, 277-297.

Bank Indonesia. (2017). Kajian Stabilitas Keuangan - Mitigasi Risiko Sistemik Melalui Penguatan Koordinasi Antar Institusi di Tengah Konsolidasi Perekonomian Domestik. KSK Maret 2017. Bank Indonesia.

Beaton, K., Myrvoda, A., Thompson, S. (2016). Non-Performing Loans in the ECCU: Determinants and Macroeconomic Impact, IMF Working Paper WP/16/229.

Beck, R. Jakubik, P. and Piloiu, A. (2015). Key Determinants of Non-performing Loans: New Evidence from a Global Sample. Open Economies Review, Springer, vol. 26 (3), 525-550, July.

Buncic, D. and Melecky, M.. (2012). Macroprudential Stress Testing of Credit RiskA Practical Approach for Policy Makers, World Bank Policy Research Working Paper No.5936.

Curak, M., Pepur, S., Poposki, K. (2013). Determinants of Non-performing Loans - evidence from Southeastern European banking systems, Banks and Bank System. Volume 8, Issue I, 2013.

Firmansyah, I. (2014). Determinant of Non Performing Loan : The Case of Islamic Bank in Indonesia. Bulletin of Monetary, Economics, and Banking, Volume 17, Number 2, October 2014.

Jakubik, P. and Reininger, T. (2013). What are the Key Determinants of Nonperforming Loans in CESEE. Focus on European Economic Integration Q3/13.

Judson, R. and Owen, L. (1999). Estimating Dynamic Panel Data Models: A Guide for Macroeconomists. Economic Letters, 65, 9-15.

Klein, Nir. (2013). Non-Performing Loans in CESEE: Determinants and Impact on Macroeconomic Performance, IMF Working Paper WP/13/72.

Nickell, S. (1981). Biases in Dynamic Models with Fixed Effects. Econometrica, 49, 1399-1416.

Nkusu, M. (2011). Nonperforming Loans and Macrofinancial Vulnerabilities in Advanced Economies, IMF Working Paper WP/11/161.

Sari, B.W., Priyarsono, D.S., Anggraeni, L. (2015). Bank-Specific and Macroeconomic Determinants of Non-Performing Loan of Regional Development Banks in Indonesia. International Journal of Science and Research (IJSR).

Surjaningsih, N., et al. (2016). Implementasi Skenario Makro dan Solvency Stress Test. Mimeo. Bank Indonesia.

Vatansever, M. and Hepsen, A. (2013). Determining Impacts on Non-Performing Loan Ratio in Turkey. Journal of Finance and Investment Analysis, vol.2 no.4. 


\section{APPENDIX}

Table A1. presents results for fixed effect regressions corresponding to different types of credit exposures, where (lagged) coefficients of explanatory variables are added up to simplify the interpretation of results.

\begin{tabular}{|c|c|c|c|c|c|c|c|c|c|c|}
\hline \multirow[b]{2}{*}{ Variables } & \multicolumn{2}{|c|}{ Commodity } & \multicolumn{2}{|c|}{ Trade } & \multicolumn{2}{|c|}{ Manufacturing Industry } & \multicolumn{2}{|c|}{ Construction } & \multicolumn{2}{|c|}{ Others } \\
\hline & $\begin{array}{c}\text { Sum of } \\
\text { Coefficient }\end{array}$ & $\begin{array}{c}\text { Marginal } \\
\text { Significance }\end{array}$ & $\begin{array}{c}\text { Sum of } \\
\text { Coefficient }\end{array}$ & $\begin{array}{c}\text { Marginal } \\
\text { Significance }\end{array}$ & $\begin{array}{c}\text { Sum of } \\
\text { Coefficient }\end{array}$ & $\begin{array}{c}\text { Marginal } \\
\text { Significance }\end{array}$ & $\begin{array}{c}\text { Sum of } \\
\text { Coefficient }\end{array}$ & $\begin{array}{c}\text { Marginal } \\
\text { Significance }\end{array}$ & $\begin{array}{c}\text { Sum of } \\
\text { Coefficient }\end{array}$ & $\begin{array}{c}\text { Marginal } \\
\text { Significance }\end{array}$ \\
\hline Rgdpsa_q & -0.2198 & 0.0032 & -0.1471 & 0.0202 & -0.1462 & 0.0185 & 0.0226 & 0.0286 & -0.1185 & 0.0843 \\
\hline Chpolrate & -0.0272 & 0.0006 & 0.0221 & 0.0193 & & & 0.046 & 0.0551 & -0.0035 & 0 \\
\hline Nexr_q & & & & & & & & & & \\
\hline Comp_q & & & -0.004 & 0.0519 & 0.0026 & 0.0533 & & & 0.0008 & 0.1625 \\
\hline Hp_q & & & -0.0248 & 0.0163 & -0.0723 & 0 & 0.0223 & 0.0005 & & \\
\hline
\end{tabular}

Table A2. presents results for GMM estimation corresponding to different types of credit exposures, where (lagged) coefficients of explanatory variables are added up to simplify the interpretation of results.

\begin{tabular}{lrrrrrrrrrr}
\hline & \multicolumn{2}{c}{ Commodity } & \multicolumn{2}{c}{ Trade } & \multicolumn{2}{c}{ Manufacturing Industry } & \multicolumn{2}{c}{ Construction } & \multicolumn{2}{c}{ Others } \\
\cline { 2 - 12 } Variables & $\begin{array}{c}\text { Sum of } \\
\text { Coefficient }\end{array}$ & $\begin{array}{c}\text { Marginal } \\
\text { Significance }\end{array}$ & $\begin{array}{c}\text { Sum of } \\
\text { Coefficient }\end{array}$ & $\begin{array}{c}\text { Marginal } \\
\text { Significance }\end{array}$ & $\begin{array}{c}\text { Sum of } \\
\text { Coefficient }\end{array}$ & $\begin{array}{c}\text { Marginal } \\
\text { Significance }\end{array}$ & $\begin{array}{c}\text { Sum of } \\
\text { Coefficient }\end{array}$ & $\begin{array}{c}\text { Marginal } \\
\text { Significance }\end{array}$ & $\begin{array}{c}\text { Sum of } \\
\text { Coefficient }\end{array}$ & $\begin{array}{c}\text { Marginal } \\
\text { Significance }\end{array}$ \\
\hline Rgdpsa_q & -0.173 & 0.0655 & -0.119 & 0.1885 & -0.191 & 0.0034 & 0.060 & 0.0514 & -0.012 & 0.3692 \\
Chpolrate & -0.029 & 0.0002 & 0.015 & 0.0377 & & & 0.057 & 0.0070 & -0.001 & 0.0001 \\
Comp_q & & & -0.004 & 0.2680 & 0.004 & 0.1641 & & & -0.003 & 0.0268 \\
Hp_q & & & -0.029 & 0.0357 & -0.088 & 0.0000 & 0.028 & 0.0001 & & \\
\hline
\end{tabular}


This page is intentionally left blank 